DOI: $10.4274 /$ tftr.56.91

\title{
Rehabilitation of Tendon Transfers for Radial Nerve Injury: A Report of Two Cases
}

\author{
Radial Sinir Felcinde Uygulanan Tendon Transferi ve Rehabilitasyonu: Iki Olgu Sunumu
}

\author{
Ali AYDENIZ, Arif TÜRKMEN*, Özlem ALTINDAĞ, Savaş GÜRSOY \\ Gaziantep Üniversitesi Tıp Fakültesi, Fiziksel Tıp ve Rehabilitasyon Anabilim Dalı, Gaziantep, Türkiye \\ *Gaziantep Üniversitesi Tıp Fakültesi, Plastik ve Rekonstruktif Cerrahi Anabilim Dalı, Gaziantep, Türkiye
}

\section{Summary}

Extended delay in the treatment of radial nerve injuries might lead to permanent loss of motor end-plate function. In such cases tendon transfer is mandatory for regaining hand functions. The postoperative management of tendon transfer is difficult and requires patient cooperation and close follow-up. Two case reports are presented to describe the postoperative course of tendon transfer for radial nerve palsy. Turk J Phys Med Rehab 2010;56:91-3.

Key Words: Radial nerve injury, tendon transfer, rehabilitation

\section{Özet}

Radial sinir yaralanmasının tedavisinde gecikme, nöromüsküler bileşke işlevlerinin kalıcı yitimine yol açabilir. Bu durumda elin işlevini yeniden kazanması için tendon transferi gereklidir. Cerrahi sonrası rehabilitasyon zor bir süreçtir ve yakın izlem ve hasta kooperasyonu gerektirir. Bu yazıda radial sinir felci nedeniyle izlediğimiz iki olgunun sonuçları belirtilmiştir. Türk Fiz Tıp Rehab Derg 2010;56:91-3.

Anahtar Kelimeler: Radial sinir yaralanması, tendon transferi, rehabilitasyon

\section{Introduction}

Radial nerve palsy is the most common peripheral nerve injury and approximately $12 \%$ of humeral shaft fractures are complicated by a radial nerve paralysis (1-3). The functional deficit in radial nerve palsy consists of inability to extend the wrist and fingers, and extend and radially abduct the thumb (4). Tendon transfers are performed by diverting a tendon insertion of a still functional muscle to another tendon. The aim is to correct the disturbed mechanical balance in the affected upper extremity, when radial nerve recovery is no longer expected from spontaneous recovery or surgical repair. Muscle-tendon re-education is the cornerstone of postoperative rehabilitation (5-6).

We report two cases of complete radial nerve palsy after humeral fracture that underwent tendon transfer surgery to reestablish wrist and finger extension. Rehabilitation is an integral part of the post-transfer radial nerve palsy management. It is a relatively hard process, which requires an active interaction and understanding of the patient, as well as team approach of rehabilitation group and reconstructive surgeons.

\section{Case Report}

\section{Case 1}

A 36-year-old woman was involved in a motor vehicle accident and presented to emergency department. Radiographs revealed minimally displaced humeral shaft fracture with clinical signs of radial nerve palsy. Her early treatment was planned as a immobilization in a long-arm cast for a period of three weeks and reexamination of the radial nerve. After cast removal, she still had wrist and finger drop. The patient showed no improvement in hand functions during the following three months and was referred to physical 
medicine and rehabilitation department. Neurological examination revealed a severe decrease in the muscle power of the wrist and finger extensor muscles and a slight brachioradialis paresis (Figure 1). Electromyography revealed signs of complete denervation of radial nerve. The patient was followed for 6 months and passive exercises of all involved joints have been applied. No functional recovery has been observed after 6 months and tendon transfer has been planned by the rehabilitation team and plastic surgeons. Brand's procedure $(7,8)$ was performed, which consists of;

a) Transfer of pronator teres (PT) to extensor carpi radialis brevis (ECRB) for wrist extension,

b) Flexor carpi radialis (FCR) to extensor digitorum communis (EDC) tendons for finger extension,

C) Ring finger flexor digitorum superficialis (FDS) to extensor pollicis longus (EPL) for thumb extension.

The transfer of palmaris longus $(\mathrm{PL})$ tendon is the transfer of choice for thumb extension, which was not present in our patient (this is seen in about $15-20 \%$ of cases) (Figure 2 ).

\section{Case 2}

A 23-year-old woman had a closed fracture of the humerus nearly one year ago. Exploration and nerve grafting had been performed 6 months ago with an intra-operative diagnosis of complete severance of the radial nerve. Functional electrical stimulation and upper extremity exercises were applied for a period of 3 weeks. The patient was encouraged to repeat the exercises at home. At the 6th month, there was no clinical or EMG evidence of improvement. A surgery was performed by plastic surgeons at the same university. The same surgical

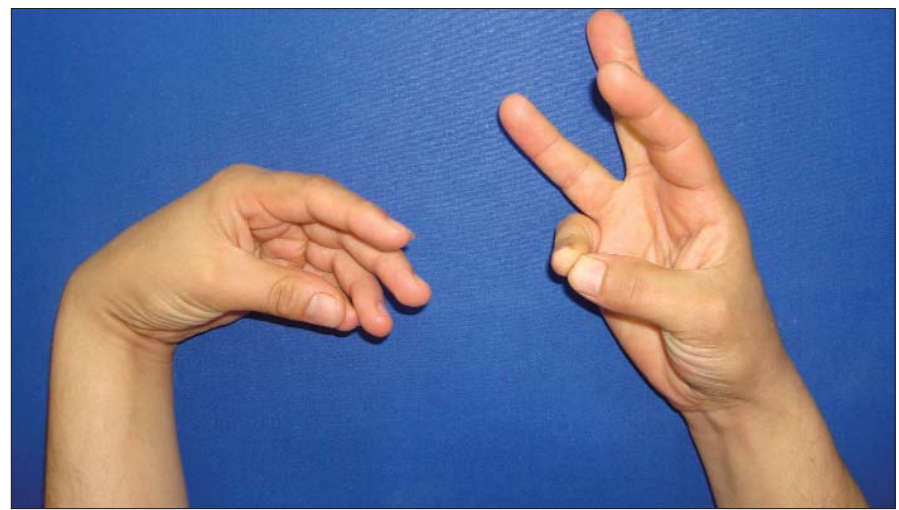

Figure 1. Wrist functions before the surgery.

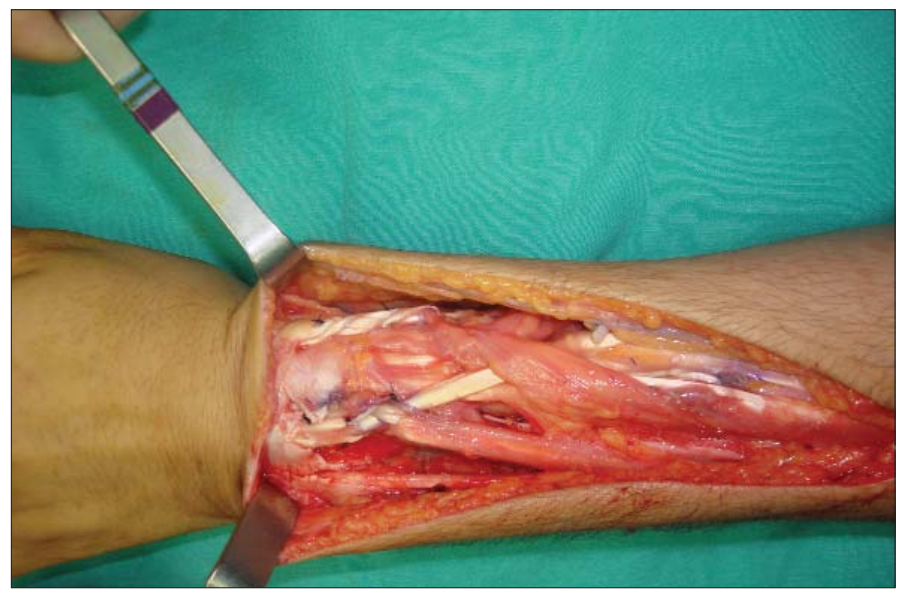

Figure 2. The tendon transfer procedure. procedure was applied, except for the transfer of PL to EPL instead of ring EDC, hence PL tendon was available in this patient.

\section{Post-operative Management}

The hand was immobilized in a splint, with the wrist in 30 degrees of extension position and metacarpophalangeal and interphalangeal joints in neutral position for three weeks (9). At the fourth week, the splint was removed and the patient was encouraged to perform massage and tendon gliding exercises for scar management, which is an important part of the rehabilitation process. The muscle-tendon re-education exercises were also promoted. The patient was motivated to perform wrist extension synergistically with finger flexion and wrist flexion with finger extension. At the 6th week, active extension and flexion of fingers and wrist were allowed.

At the 8th week, both patients gained $40^{\circ}$ wrist and full extension of the digits, which is necessary for functional use of the hand (Figure 3 ).

\section{Discussion}

Close anatomic relationship of the radial nerve with the middle and distal third of the humerus frequently leads to radial nerve palsy after midshaft fractures. In these cases, a detailed examination and clinical suspicion towards nerve injury should also be maintained (10). Tendon transfer provides good results in cases, in which in spite of all conservative and surgical interventions, no recovery is observed and permanent radial nerve palsy is present. Postoperative course after tendon transfer is difficult and requires patient cooperation and close follow-up. The scar tissue can limit motion of the involved tendons and adjacent structures. Thus, it should be kept in mind that scar tissue can establish new transfer and hold it in position. Early tendon gliding is the most efficacious method for prevention of adhesion formation. Higher tensile force on the re-directed tendon might cause rupture. Re-education of muscle-tendon unit is an important part of the rehabilitation following tendon transfers. Use of verbal cues to perform the previous action prior to transfer is an effective prompt. The patients should be motivated to do the combined motions for wrist extension, pronation of the forearm and simultaneously wrist extension (11).

In conclusion, radial nerve palsy management is a relatively difficult process, which requires an integrated team approach of rehabilitation team and reconstructive surgeons.

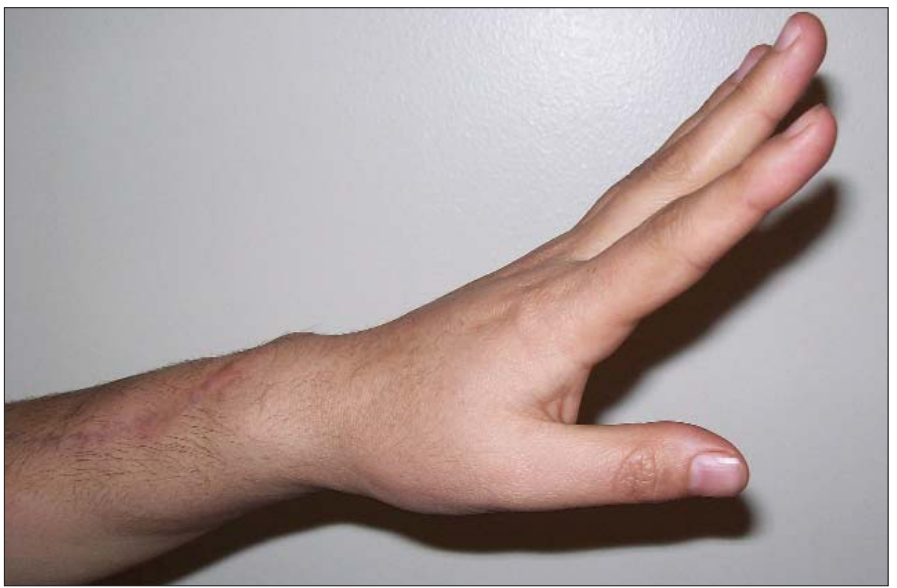

Figure 3. Hand functions after two months of rehabilitation. 


\section{References}

1. Ristic S, Strauch RJ, Rosenwasser MP. The assessment and treatment of nerve dysfunction after trauma around the elbow. Clin Orthop Relat Res 2000;370:138-53. [Abstract]

2. Chapman JR, Henley MB, Agel J, Benca PJ. Randomized prospective study of humeral shaft fracture fixation: intramedullary nails versus plates. J Orthop Trauma 2000;14:162-6. [Abstract]

3. Yang $\mathrm{KH}, \mathrm{Han} \mathrm{DY}$, Kim HJ. Intramedullary entrapment of the radial nerve associated with humeral shaft fracture. J Orthop Trauma 1997;11:224-6. [Abstract]

4. Thomsen NO, Dahlin LB. Injury to the radial nerve caused by fracture of the humeral shaft: timing and neurobiological aspects related to treatment and diagnosis. Scand J Plast Reconstr Surg Hand Surg 2007;41:153-7. [Abstract] / [PDF]

5. Kruft S, von Heimburg D, Reill P. Treatment of irreversible lesion of the radial nerve by tendon transfer: indication and long-term results of the Merle d'Aubigné procedure. Plast Reconstr Surg 1997;100:610-6. [Abstract]
6. Tubiana R. Problems and solutions in palliative tendon transfer surgery for radial nerve palsy. Tech Hand Up Extrem Surg 2002;6:104-13. [Abstract]

7. Papadopoulou M, Spengos K, Papapostolou A, Tsivgoulis G, Karandreas $\mathrm{N}$. Intraoperative radial nerve injury during coronary artery surgery-report of two cases. J Brachial Plex Peripher Nerve Inj 2006;5:1-7. [Abstract] / [Full Text] / [PDF]

8. Brand PW. Tendon transfers for median and ulnar nerve paralysis. Orthop Clin North Am 1970;1:447-54. [Abstract]

9. Chu PJ, Lee HM, Hou YT, Hung ST, Chen JK, Shih JT. Extensor-tendons reconstruction using autogenous palmaris longus tendon grafting for rheumatoid arthritis patients. J Orthop Surg Res 2008;24;3-16. [Abstract] / [Full Text] / [PDF]

10. Ekholm R, Ponzer S, Törnkvist H, Adami J, Tidermark J. Primary radial nerve palsy in patients with acute humeral shaft fractures. J Orthop Trauma 2008;22:408-14. [Abstract]

11. Lowe JB 3rd, Sen SK, Mackinnon SE. Current approach to radial nerve paralysis. Plast Reconstr Surg 2002;110:1099-113. [Abstract] 